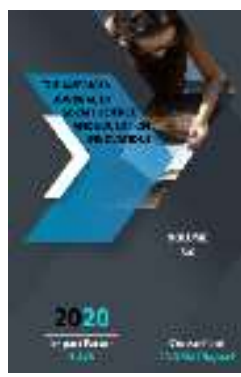

\title{
Some Features Syrian Foreign Policy On The Middle East
}

Nodir Abdullaev

Phd In Political Sciences, Tashkent State University Of Oriental Studies, Uzbekistan

Journal Website:

http://usajournalshub.c

om/index,php/tajssei

Copyright: Original

content from this work may be used under the terms of the creative commons attributes 4.0 licence.

\section{ABSTRACT}

These days, the Middle East remains one of the most explosive regions in the world. Today, Syria has become a kind of core of the global political crisis. This article inspects the political prerequisites for the emergence and development of the regional problem, reveals its features, and analyzes the external factors that have had and are still having an impact on the evolution of the Middle East problem. The article studies the preconditions for the growth of conflict potential and exacerbation of the struggle for influence in the Middle East. The role of Syria in the competition between the leading Arab countries and Iran for regional leadership is considered and conclusions are drawn about the goals pursued by them in the Middle East. The article examines the formation of Syria's foreign policy, analyzes the influence of the Palestinian factor on its regional policy, and reveals the position of Syria on the Lebanese problem. A number of factors influencing the evolution of Syria's foreign policy in the new geopolitical situation in the region are analyzed.

\section{KEYWORDS}

Middle East, Syria, Syrian crisis, Syrian position, peace process, Palestine-Israel conflict, leading countries, factors, conflict, foreign policy, Sunnis, Shia, Arab spring.

\section{INTRODUCTION}

The Arab world is experiencing a wave of political alteration and disturbance, which has led to political transformation and has become the basis of new political processes. The new 
political thinking, emerging in the international relations, requires rethinking of pre-existing principles and approaches to solving conflict situations. Expert and analytical circles are paying special attention to the ongoing political processes in the Middle East. In this regard, for the orientalists and political scientists of great interest is the Syrian problem, in which there are serious changes due to the socio-political realities of the modern world. The Middle East is constantly the arena of confrontation between the United States and Russia. In the current conditions, when the influence of Russia, which has its strategic interests in the Middle East, is strengthening in the political arena of the Arab countries, the military-political positions of the countries of the region are changing qualitatively.

It should be noted that Russian interest in Syria is due to not only political aspects and factors of national security, but also has an economic implication. Of particular relevance is the realization of the national interests of the Middle East countries themselves, in particular Syria, which has an important place in the region both in political and military relations. After gaining full-scale Russian support, there were cardinal transformations in Syrian foreign policy.

\section{THE MAIN PART}

Analyses of Syria's political, economic and military development, its place and role in international relations, Syria's relationship with neighboring Arab States, as well as their evolution reveal particular interest. Currently, in the context of the intensification of political processes in the region, there is a need for scientific analysis of the history of Syria's foreign policy. In this regard, the study of the dynamics of Syria's foreign policy in the Middle
East region is of particular relevance. Syria was one of the first Arab countries to achieve political independence. However, the subsequent history of Syria has become a history of persistent struggle for the preservation and consolidation of political independence and the achievement of economic independence, democracy and social progress.

Thus, the American researcher G.Fuller, revealing the attitude of the United States to the Middle East region as a whole, notes that: "The Middle East for Americans was the intransigence of national passions, religious identity and the danger of political explosions" (G., 1990)." Another American researcher H.Cobban (H, 1985.), by analyzing the political processes in the region, focuses on the problems of deployment of forces in the Middle East, the development of the regional conflict and the intervention of foreign countries in it, as well as the use of various political and military means by Syria.

The events, which take place in the Middle East, necessitate the rejection of external political forces from the strategies and technologies of influence traditionally used by them. Despite their commitment to traditionalism, the leading states are trying to ensure their national interests by changing the form and scale of their presence, balancing between "hard" and "soft" means of influencing the political process in the region. Of decisive importance in the context of influence on the Middle East political process are the strategies and technologies implemented by the United States. Over a long period, this superpower has developed and implemented a variety of technologies of influence in relation to the peculiarities of the political process in the Gulf. In order to resolve the conflict situation and predict its further development, it is essential to study the 
evolution of strategies and technologies used in relation to the Arab countries. The Arab spring reflected the profound transformation processes taking place in the modern system of international relations. Arab unrest shows a general tendency to their marginalization, the complication of the social aspect in the context of globalization, which was particularly acute in the context of the world crisis. The hierarchy of key players in the global arena is changing. (Avatkov V., Sokolova N.)

Despite the fact that the reason for the growth of discontent among the masses was such internal contradictions as interfaith tensions, unsuccessful liberal reforms, alienation between the government and the people that have accumulated in Syrian society, a significant factor in the escalation of protests in a full-scale civil war, was the clash of interests of external factors. The political struggle between various regional and nonregional States "fuels" the armed confrontation in the country and significantly complicates the settlement of the Syrian conflict. The "Arab spring" in Syria contributed to the increase of the potential conflict and strengthening the struggle in the Middle East between Iran, Saudi Arabia and Turkey, becoming a catalyst for the escalation of ethnic and religious tensions. One of the main reasons for the involvement of regional powers in the Syrian conflict was the aggravation of the Sunni-Shiite confrontation in the whole territory of the Middle East.

There is a considerable amount of research on the political influence of global and regional factors on the political process in the Middle East. Firstly, should be noted the works of Arab authors representing the political science of the region. Despite the dominance of historical studies in the Arab literature, there are also analytical works of a political nature, containing attempts to consider certain political processes in the system and dynamics of regional and global relations.

Most studies of American historians and political scientists on the problems of political relations in the Middle East differentiate with its coverage of the analyzed topics, conceptual approaches to the assessment of the role of the US and leading Arab countries. On the other hand, these works are also characterized by political bias, extreme subjectivism in assessing the role of the United States. Currently, political science has formed a separate direction in the study of problems of intraregional political relations in the Middle East. The main ones are the study of the strategy and tactics of the United States and Russia in the region, the study of the policy of Arab countries.

The study of Syria's foreign policy in the context of the analysis of the Middle East problem allows us to adequately assess the conflict, identify the main causes of its occurrence, identify factors and means that affect the course of development of international relations in the Middle East in general, and the regional policy of Syria, in particular.

The great changes that took place in the international arena in the early gos of the twentieth century led to positive changes in the settlement of the Middle East problem. Analysis of the factors and means that determine the nature of this regional problem, allowed determining that ideological contradictions between the conflicting parties did not play a decisive role, so the desire of Syria to have good relations with the former Soviet Union and to use its support pursued largely the national interests itself. Based on the analysis of political prerequisites and 
reasons for the evolution of inter-state relations in the region, the presence of complex multi-vector relations between the conflicting parties is revealed. Such an analysis makes it possible to determine the evolution of inter-state relations in the Middle East as a process that has a certain positive orientation, in particular, the bloc orientation of a number of Arab countries that has passed into the past.

Based on the specific aspects of the Middle East problem, the ways of ensuring security in the region as a whole can be outlined in the form of three main schemes. First, to involve Middle Eastern countries into the various aspects of security and military-political union, second, the establishment of a system of mutual guarantees, and "elective" options agreement, third, the creation of a universal system of regional security. Despite the attractiveness of the first two schemes, the establishment of a collective security system in the region has more positive prospects, since it takes into account the interests of all countries of the Middle East.

The analysis of the formation of the Syrian foreign policy doctrine in solving the middle East problem reveals the active role of the Syrian armed forces in the development of the main directions of its foreign policy activities, which is due to a number of reasons arising from the peculiarities of the military-political situation in the region itself, contributing to the unification of Syria's strategic objectives in the political and military spheres. It also meets the interests of Syria, aimed at ensuring its leading position in the region. Syrian diplomacy is based on the idea according to which the creation of a security system in the Middle East region should take into account different levels of interests - national, regional, inter-Arab and international. At the same time, it is important to develop and strengthen a well-thought-out unified position of all Arab countries in relation to the Arab-Israeli conflict, which is a determining condition for building a multifaceted system of regional security and in the perspective can strengthen the political authority of the Syrian Arab Republic in the region.

Negotiation processes at various levels with the participation of states involved in the Middle East conflict, show that this problem is changing qualitatively, while maintaining its priority in the foreign policy of both Syria and other Arab countries. At the same time, the political solution of the Middle East problem is not fully provided by economic factors. As the Middle East turns towards peace, competition among the intermediary countries that have interests in the region is intensifying.

Studying the prospects for peace processes in the Middle East makes it possible to determine that the fate of these processes depends on the position of Israel. The analysis of the SyrianIsraeli relations regarding the Middle East problem shows the difficulty of establishing normal relations between these countries, which is due to Syria's distrust of the often changing position of Israel.

At the same time, the existence of serious disagreements between the various Palestinian factions and the difference in their positions with regard to the Middle East settlement are seen as obstacles to the achievement of mutual understanding between Syria and Palestinian organizations. The settlement of the conflict in the Middle East is also complicated by the existence of the Syrian-Lebanese conflict. The study of this problem allows to define it as a situation that initially has multi-vector and multi-factor characteristics. The development of political processes in Lebanon, their complexity and 
inconsistency in the gos of the twentieth century contributed to the strengthening of Syria's position in the political life of Lebanon. First of all, the events in Lebanon did not arise only because of internal Lebanese problems; it is most likely a reaction to the deterioration of the political situation in the Arab world and in international relations. Syria's desire to establish a balance of power in Lebanon meets its geopolitical and strategic interests.

In this regard, it should be noted that one of the main directions of Syria's foreign policy towards Lebanon is to counter the strengthening of Israel's positions. Syria has a strategic goal aimed at creating a favorable "buffer zone" in Lebanon. At the same time, the analysis of the political processes of the 90ies of the twentieth century led to the conclusion that Syria is strengthening its presence in the negotiations to resolve the multi-vector and very complex Middle East problem, where the Palestinian factor plays a decisive role.

The growing disagreements between Syria and Turkey confirm the assumptions of Egypt and Saudi Arabia that the geopolitical content of international relations is changing in the region. The complication of Syrian-Turkish relations shows that the interests of Turkey and other countries are intertwined here. Analysis of the confrontation between Syria and Turkey has determined that despite the USA calls to resolve everything in a peaceful way, the United States is ambiguous about the security of Turkey. At the same time, the Arab League seeks to prevent the infringement of the interests of Syria. Nevertheless, the continuing danger from Turkey is also due to the fact that the Syrian-Turkish problems as a whole remain unresolved.

The study of possible solutions to this problem allows to determine that there are two important points that could bring together the
Syrian-Turkish positions: firstly, the Syrian Arab Republic under any circumstances would not support the creation of a Kurdish state; secondly, both sides, both Syria and Turkey, in principle, do not want the existing problems between them to develop into open and prolonged military clashes.

\section{CONCLUSION}

In summary, it should be noted that the most important principle of Syria's foreign policy at the present stage is that in the new geopolitical conditions in the region, it is necessary to create a strong Arab bloc, develop a unified position of the Arab countries. Syrian diplomacy proceeds from the premise that the formation of a regional security system should be carried out both at the level of international and inter-Arab relations, which will strengthen the guarantees of a solution to the Middle East problem.

Ending the civil war in Syria is impossible without resolving the contradictions between Russia, the United States, Turkey, Israel, Saudi Arabia and Iran. The cessation of hostilities can be realized after the establishment of political dialogue and mutual concessions.

In the Middle East, interstate foreign policy competition between the United States and Russia is growing. The significance and some strengthening of the "Eastern" - Russian factor of influence are seen.

The emergence of a new geopolitical situation in the region has further intensified the role of the military factor in solving the Middle East problem. The military continues to occupy an important place in the foreign policy of the countries of the region, in particular, Syria. At the same time, sharp differences remain among the Arab countries themselves. This is largely reflected in the difference and even 
contradiction of their positions on various problems in the region. Syrian diplomacy acts on the assumption that the formation of a regional security system should be carried out in various directions: national, regional, international, as well as among the Arab countries themselves, taking into account the interests of all parties.

\section{REFERENCES}

1. Avatkov V., Sokolova N. https://otherreferats.allbest.ru/interna tional/ 00265197_o.html

2. Dolgov B.V. Democracy and Islamism in the Arab world (Algeria, Tunisia, Egypt). Elek.biblioteka Museum of Anthropology and Ethnography RAN http://www.kunstkamera.ru/lib/rubrika tor/03/03_04/978-5-02-025251-6/

3. Korolkov L. Menyayushchayasya geometry blijnevostochnyx raskladov // International processes. 2015. T. 13. №1. http://www.intertrends.ru/fortieth/Kor ol\%27kov.pdf

4. Sapronova M. Stanovlenie novoy gosudarstvennosti na Arabskom Vostoke. International Processes, Volume 13, № 3, ss. 26-39DOI 10.17994 /

IT.2015.13.2.42.2

5. Fuller G. The Middle East in US - Soviet Relations. // Middle East Journal. Vol. 44, No.3, Summer 1990, - P.417.

6. Berman I. Tightening the economic noose - curbing Iran's nuclear ambitions // Middle East Quarterly. 2013. Summer. http://www.ilanberman.com/ 10092/tightening-the-economic-noose

7. Cobban H. The Making of Modern Lebanon. - L.: Hutchinson, 1985 